\title{
Target delineation and optimal radiosurgical dose for pituitary tumors
}

Giuseppe Minniti ${ }^{1,2^{*}}$, Mattia Falchetto Osti ${ }^{1}$ and Maximillian Niyazi ${ }^{3}$

\begin{abstract}
Stereotactic radiosurgery (SRS) delivered as either single-fraction or multi-fraction SRS (2-5 fractions) is frequently employed in patients with residual or recurrent pituitary adenoma. The most common delivery systems used for SRS include the cobalt-60 system Gamma Knife, the CyberKnife (CK) robotic radiosurgery system, or a modified conventional radiotherapy machine (linear accelerator, LINAC). Tumor control and normalization of hormone hypersecretion have been reported in $75-100 \%$ and $25-80 \%$ of patients, respectively. Hypopituitarism is the most commonly reported late complication of radiation treatment, whereas other toxicities occur less frequently. We have provided an overview of the recent available literature on SRS in patients with a pituitary adenoma. Critical aspects of pituitary irradiation, including target delineation and doses to organs at risk, optimal radiation dose, as well as the long-term efficacy and toxicity of SRS for either nonfunctioning or secreting pituitary adenomas are discussed. Single-fraction SRS represents an effective treatment for patients with a pituitary adenoma; however, caution should be used for lesions $>2.5-3 \mathrm{~cm}$ in size and/or involving the anterior optic pathway. Future studies will be necessary to optimize target doses and critical organ dose constrains in order to reduce the long-term toxicity of treatments while maintaining high efficacy.
\end{abstract}

Keywords: Fractionated stereotactic radiotherapy, Radiosurgery, Pituitary adenoma, Acromegaly, Cushing's disease, Target delineation

\section{Introduction}

Conventional radiation therapy (CRT) has traditionally been used in patients with residual or recurrent secreting and nonfunctioning pituitary adenomas who have failed prior medical management and/or surgery, resulting in a variable long-term tumor control of $87-95 \%$ at 10 years [1-4], and normalization of elevated plasma levels of growth hormone $(\mathrm{GH})$ and adrenocorticotropic hormone $(\mathrm{ACTH})$ in up to $55 \%$, and $78 \%$ of patients, respectively [5-8]. Hypopituitarism occurs in 30-60\% of patients 5-10 years after irradiation, while other toxicities, including radiation-induced optic neuropathy, cerebrovascular accidents, and secondary tumors have been reported in $0-5 \%$ [9-12].

Stereotactic radiosurgery (SRS) is a sophisticated radiation therapy technique that precisely delivers high dose of irradiation in a single o few (2-5) fractions to welldefined, small-to-moderate brain targets. SRS allows for

\footnotetext{
* Correspondence: giuseppeminniti@libero.it

${ }^{1}$ Unit of Radiation Oncology, Sant' Andrea Hospital, University Sapienza, Rome, Italy

${ }^{2}$ IRCCS Neuromed, Pozzilli (IS), Italy

Full list of author information is available at the end of the article
}

more precise target localization and accurate dose delivery as compared with CRT, resulting in a reduction of the volume of normal brain tissue irradiated to high radiation doses [13]. The techniques used for the treatment of a pituitary adenoma involve the Gamma Knife (GK) [14], the CyberKnife (CK) robotic radiosurgery system $[15,16]$, or a modified conventional radiotherapy machine (linear accelerator, LINAC) [17, 18]. Data from literature report a tumor control after SRS up to $97 \%$ at 5 years, with normalization of hormone hypersecretion in more than $50 \%$ of patients [19]. Hypopituitarism is the most commonly reported late complication of treatment, whereas other late radiation-induced complications are low. As high doses are delivered to the tumor with the use of the stereotactic radiosurgical techniques, an accurate delineation of target and surrounding normal brain structures becomes increasingly important to minimize radiation-induced toxicity while maintaining high tumor control.

We aimed to provide a critical review of the different aspects of radiosurgical techniques for pituitary tumors, including the delineation of target and critical organs, 
technical characteristics of the different types of SRS delivery systems, the optimal dose and fractionation for nonfunctioning and secreting pituitary adenomas, and the long-term efficacy and toxicity.

\section{Methods and materials}

A literature search was conducted in MEDLINE PubMed that evaluated adults with pituitary adenomas. The search focused on randomized, prospective and retrospective studies published in English. The searches were limited by date from January, 2000 to November, 2015 using a combination of medical subject headings (MeSH) ("pituitary adenomas/radiosurgery" or "nonfunctioning pituitary adenomas" or "acromegaly" or "Cushing disease" or "prolactinomas") and free text terms ("toxicity" or "hypopituitarism" or "target delineation" or "radiosurgical dose" or "fractionated radiosurgery" or "organs at risk"). Articles were excluded from the review if they: had a non-English abstract, were not available through Pubmed, were pediatric series or case studies involving less than 8 patients, or were duplicated publications. To identify additional articles, the references of articles identified through the formal searches were scanned for additional sources. A total of 984 potentially relevant studies were identified. Finally, 92 studies reporting the clinical outcomes of SRS for either nonfunctioning or secreting pituitary adenomas with a minimum follow-up of 1 year were selected and included in the review.

\section{Target delineation}

Defining the optimal target volume for a pituitary adenoma represents a balance between minimizing treatment-related toxicity while maintaining a high tumor control. Current optimal imaging technique for target delineation requires the use of precontrast and postcontrast magnetic resonance imaging (MRI) sequences to improve the accuracy of target identification and delineation. Contrast-enhanced 3D T1-weighted sequences with $1 \mathrm{~mm}$ thin slices are extremely useful for accurate target delineation by allowing identification of subtle enhancement patterns in the surrounding neurovascular structures and along the course of the optic nerve [20]. For planning purpose, MRI scan is subsequently fused with thin-slice non-contrast enahnaced CT scan. Although a displacement up to $2.8 \mathrm{~mm}$ has been reported for brain soft-tissue based fusion, the magnitude of displacement is considered negligible for lesions of the skull base due to its rigidity and great visibility in all imaging modalities [21]; so far, no additional margins would be required to ensure adequate target coverage during SRS to compensate fusion uncertainties. Since most pituitary adenomas are benign, slow-growing neoplasms, peritumoral edema is generally absent. For this reason, T2-weighted images, which are extremely useful in evaluating the parenchyma of the brain and the perilesional edema, are not generally used for target volume delineation. Preoperative MRI may be helpful to discern postoperative changes from tumor, especially in patients who had undergone several prior surgeries. Similarly, contrast-enhanced T1-weighted images with fat suppression may be used to minimize postoperative changes that might obscure the accuracy of radiosurgical targeting. when MRI is contraindicated, a thin-slice CT imaging through the pituitary regions is performed with and without contrast administration.

The gross tumor volume (GTV) is represented by the lesion visible on MRI/CT. The clinical target volume (CTV) includes microscopic disease. In general, additional margin expansion from GTV to CTV is unnecessary in pituitary adenomas; however, a small margin may be added in the intracavernous portion of aggressive adenomas to encompass potential areas of microscopic tumor infiltration. The planning tumor volume (PTV) should take into account uncertainties of patient setup. Currently, a similar sub-millimteric accuracy of target positioning has been reported for frameless CK and LINAC based systems (Novalis Tx) and frame based GK SRS technology [14-18, 22, 23]. In most centers, a margin of $0-1 \mathrm{~mm}$ is generally used for GTV to PTV expansion; however, due to the different commercial SRS systems, each department should audit their setup results and apply the margins on the basis of their own observations.

\section{Organs at risk}

The sellar and parasellar region is an anatomically complex area including endocrine, nervous, and vascular structures. The pituitary fossa comprises the pituitary gland, which is composed of the adenohypophysis and neurohypophysis. The parasellar region encompasses the cavernous sinuses and the suprasellar cistern structures. The cavernous sinus consists of trabeculated, multilobulated venous channels which are located lateral to the sella turcica and sphenoid sinus. The cavernous sinus contains cranial nerves III (oculomotor), IV (trochlear), V1 (ophthalmic division of the trigeminal nerve), V2 (maxillary division of the trigeminal nerve) and VI (abducens). It also contains the cavernous segment of the internal carotid artery. The suprasellar cistern includes the optic chiasm and nerves, the anterior third ventricle, the hypothalamus, the pituitary infundibulum, the infundibular and suprachiasmatic recesses of the third ventricle.

A careful delineation of all organs at risk (OARs) surrounding the target volume is mandatory. OARs in the skull base region include optic nerves and chiasm, brainstem, pituitary stalk, pituitary gland, and cavernous sinus 
cranial nerves (an example of GTV and OARs contours is shown in Figs. 1 and 2). Expansion of OARs to create a planning risk volume (PRV) for each OAR may be applied; the margin, as for the GTV, should reflect the accuracy of daily set-up. Overlaps between PRVs and PTV should be considered; however, caution should be used when the reduction of the dose to the OARs may results in inadequate dose coverage of PTV. With regard to dose limits for the OARs, the optic nerves and chiasm are believed to be the most radiation-sensitive structures to SRS. A risk of radiation-induced optic neuropathy up to $2 \%$ has been reported for point doses to the optic pathway of 8-10 Gy [24-31]; however, the risk of optic neuropathy remains low for point doses of 10-12 Gy to small portions of the optic apparatus [25, 27, 29, 30]. In a retrospective series of 222 patients who received GK SRS for benign tumors adjacent to the anterior visual pathway, Leavitt et al. [29] observed no new visual

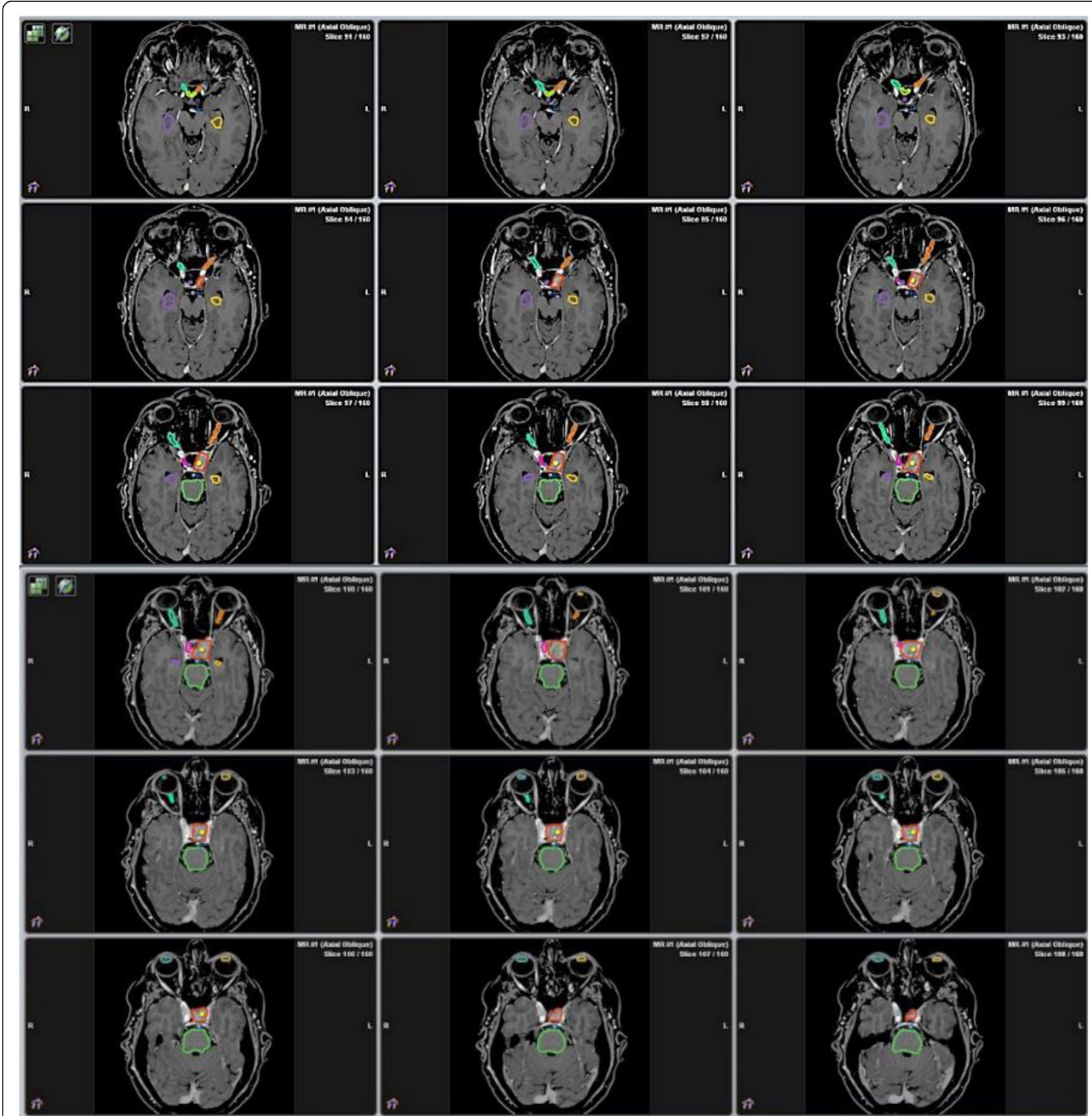

Fig. 1 Target delineation of a pituitary adenoma. Gross tumor volume/Planning target volume (GTV/PTV) and organs at risk are outlined as solid lines. GTV/PTV (red); optic chiasm (yellow); left optic nerve (orange); right optic nerve (cyan); letf lens (light yellow); right lens (light blue); brainstem (green); pituitary stalk (blue); pituitary gland (pink); right hippocampus (purple); left hippocampus (golden yellow) 


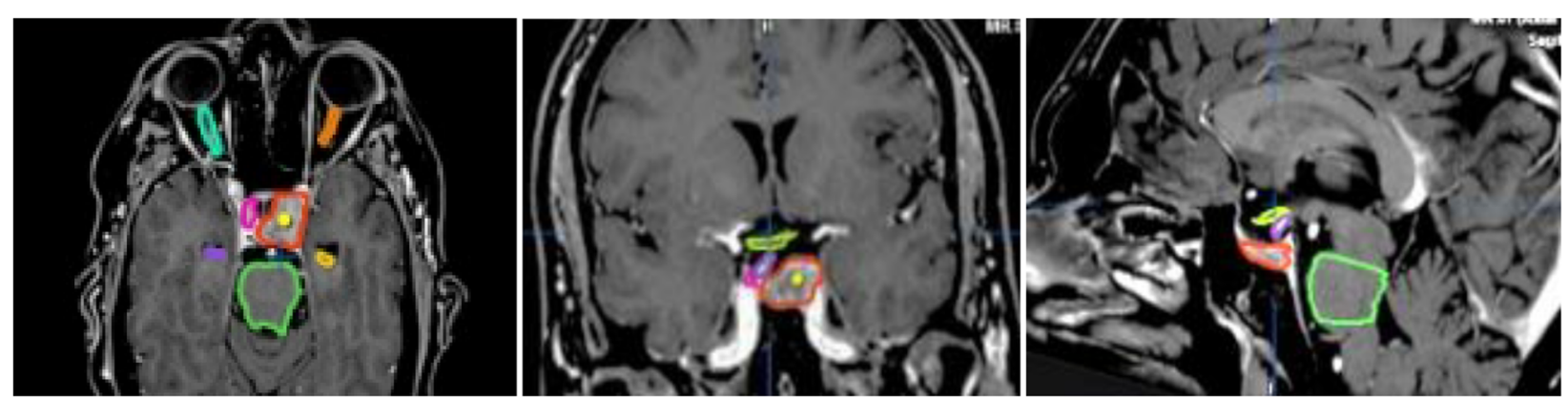

Fig. 2 Axial, coronal, and sagittal view of target delineation for a pituitary adenoma. For GTV,PTV and organs at risk, see Fig.

symptoms for patients receiving a maximum dose of 12 Gy to small portions $\left(2-4 \mathrm{~mm}^{3}\right)$ of the optic chiasm after single-fraction SRS. The risk of developing radiation-induced optic neuropathy was 0 for patients receiving a maximum point dose of $8-12$ Gy and $10 \%$ for those receiving a maximum point dose of $12-15$ Gy to the anterior optic pathway. Hasegawa et al. [27] evaluated 100 patients undergoing GK SRS for craniopharyngiomas. Two patients who received maximum radiation point doses to the optic pathway of 15 and $18 \mathrm{~Gy}$, respectively, developed optic neuropathy, whereas no visual deficits were observed in patients receiving lower doses. While these studies suggest that point doses up to 12 Gy to small portion of the optic pathway are associated with a low risk of optic neuropathy, in clinical practice a maximum point dose of $10 \mathrm{~Gy}$ is usually recommended when treating lesions adjacent to the optic pathway.

Little is known about the tolerance of the cranial nerves of the cavernous sinus. Leber et al. [25] reported no cranial nerve injury in patients receiving singlefraction SRS when doses of 5-30 Gy were delivered to the cavernous sinus. In contrast, Tishler et al. [24] reported a $13 \%$ incidence of the third and sixth cranial nerve in 62 patients undergoing GK SRS; however, they could not find a significant relationship between the delivered dose of 10-40 Gy and new or worsening deficits. Although a precise tolerance dose of cranial nerves within the cavernous sinus after single-fraction SRS cannot be defined, doses up to 18 Gy to the cavernous sinus are associated with low incidence of radiation-induced toxicity $(0-4 \%)[13,32]$.

Hypopituitarism is the most common adverse effect after SRS for a pituitary adenoma. Several studies have evaluated the relationship between radiation doses to the normal pituitary gland and distal infundibulum [33-38] and the development of hypopituitarism. Leenstra et al. [35] reported on 82 patients with either nonfunctioning or secreting pituitary adenomas who received GK SRS at the Mayo Clinic. Applying the criteria of a mean dose of 15 Gy to the pituitary gland, they noted new endocrine deficits in 12 of 40 patients (30\%) for doses < 15 Gy compared with 9 of 20 patients (45\%) who received a mean gland dose $>15$ Gy. In their analysis they found new anterior deficits in $0 \%, 29 \%, 39 \%$ and $83 \%$ for mean doses to the pituitary gland $\leq 7.5 \mathrm{~Gy}, 7.6-13.2 \mathrm{~Gy}$, 13.3-19.1 Gy, and >19.1 Gy, respectively. In another series of 85 patients treated with GK for a pituitary adenoma, Marek et al. [36] reported an incidence of hypopituitarism of $2.2 \%$ for patients irradiated with a mean dose to pituitary $<15$ Gy and $72.5 \%$ for those who received a mean dose $>15$ Gy. A significant correlation between the mean dose of 15 Gy to the pituitary gland and the development of new pituitary deficits has been reported in other studies [34, 38].

The correlation between the mean dose delivered to the pituitary stalk and the incidence of hypopituitarism has been evaluated in retrospective series [33, 34, 36, 38]. In a series of 130 patients treated with singlefraction SRS, Sicignano et al. [38] reported 5-year actuarial incidence of new pituitary deficits of $8 \%$ for a mean dose to the pituitary stalk $<7.3$ Gy and $32 \%$ for a mean dose to the pituitary stalk $>7.3 \mathrm{~Gy}$. Similarly, Feigl et al. [33] observed a significant incidence of new endocrine deficits for doses > 6.5 Gy to the pituitary stalk in a series of 108 patients treated with GK SRS for a pituitary adenoma. In contrast, Vladika et al. [34] found a significant incidence of new pituitary deficits after singlefraction SRS only for patients who received a maximum dose to the pituitary stalk $>17$ Gy. Future prospective studies with an appropriate follow-up will be necessary to better identify the maximum safe doses to the pituitary gland and the pituitary stalk. Whenever possible, mean radiation doses to the pituitary gland and stalk should be kept under 12-15 Gy and 7-10 Gy, respectively, with the aim of limiting the development of new pituitary deficits.

Other OARs include the brainstem and hippocampi. For single fraction SRS, maximum brainstem doses of $12-14$ Gy are associated with low $(<5 \%)$ risk of neurological complications, although this risk significantly increases for doses $>15$ Gy given as single fraction 
$[28,39]$. In a recent review of radiation associated brainstem toxicity, Mayo et al. [28] calculated a risk of normal tissue complication probability of $1 \%, 13 \%, 61 \%$, and $94 \%$ for partial volume irradiation of one third of the brainstem to doses of 12.5, 14.2, 16, and $17.5 \mathrm{~Gy}$, respectively. A lower risk of complications was observed when the same doses were delivered to a small partial volume (1\%) of the brainstem. Although definitive criteria of dose-volume effects on brainstem dose tolerance after single-fraction SRS remains to be better defined, in clinical practice caution should be used when delivering doses to the brainstem $>12.5$ Gy. For tumors located in the parasellar region, hippocampi can be contoured as an effort to reduce the potential negative neurocognitive effect of high radiation doses to the hippocampal region [40]; the principle of this approach is acknowledged but there is currently insufficient evidence to support recommendations on hippocampal sparing during SRS.

There is limited evidence relating tolerance of the optic apparatus and cranial nerves of the cavernous sinus after multi-fraction SRS. Retrospective studies have observed a risk of optic complications of less than $1 \%$ for patients with skull base tumors treated with doses of 21-25 Gy delivered in 3-5 fractions [41-46]. Liao et al. [45] reported the outcome of fractionated SRS delivered with a LINAC system. Thirty-four residual/recurrent pituitary adenomas with a median tumor volume of $4.11 \mathrm{~cm}^{3}$ in close proximity to the optic apparatus (median minimal distance $1 \mathrm{~mm}$, ranging from 0 to $2.5 \mathrm{~mm}$ ) were treated with a total dose fo 21 Gy in 3 fractions of 7 Gy each. With a median follow-up of 37 months, no patients developed optic neuropathy; the mean singlefraction doses to the optic nerve and chiasm were 5.58 \pm 0.98 and $4.86 \pm 0.15$ Gy, respectively. One patients developed transient diplopia after SRS, which resolved after a short course of dexamethasone. Using doses of $21 \mathrm{~Gy}$ in 3 fractions or 25 Gy in 5 fractions delivered with CK, Iwata et al. [44] reported a grade 2 visual disorder in only 1 out of 100 patients at a median follow-up of 33 months; however, no details of doses delivered at optic apparatus were provided in their study. In another study of 34 patients who received a multifraction SRS (5 $\times 5$ Gy) at University of Rome Sapienza for a skull base metastasis involving the anterior optic pathway, at a median follow-up of 13 months no optic neuropathy were observed for doses $>25$ Gy to less than one-third of optic chiasm and $>27.5$ Gy to a small volume of $0.01-$ $0.06 \mathrm{~cm}^{3}$ [46]. With regard to the cavernous sinus cranial nerves tolerance, no deficits have been reported using median doses of 20 Gy delivered in 2 to 5 fractions for perioptic lesions [41-43]. Although these studies indicate that $5 \times 5$ Gy or $3 \times 7$ Gy schedules are associated to a low risk of radiation-induced optic neuropathy and cavernous sinus cranial deficits, further studies need to better evaluate the dose-volume relations for OARs during multi-fraction SRS of patients with pituitary tumors.

\section{Treatment techniques}

SRS for pituitary adenomas is typically delivered as single-fraction SRS or, less frequently, as multi-fraction SRS (2-5 fractions). Main used techniques include the use of GK, CK or a modified LINAC [13-18]. In its new version, GK uses 192 radioactive cobalt-60 sources that are spherically arrayed in a single internal collimation system via collimator helmets to focus their beams to a center point. The tungsten collimators are organized into eight sectors of 24 sources each with three different apertures of $4 \mathrm{~mm}, 8 \mathrm{~mm}$, and $16 \mathrm{~mm}$, respectively. A highly conformal but inhomogeneous dose distribution and high central tumor dose can be achieved through the optimal combinations of the number, the aperture and the position of the collimators [14, 15, 22]. Traditionally, patients are placed in a rigid stereotactic frame achieving submilimeter accuracy in dose delivery. The dose is typically prescribed at the $50 \%$ isodose to obtain the maximum dose at the center of each pinpointed target and the prescribed dose at target edge.

CK (Accuray, Sunnyvale, CA) is a relatively new technological device that combines a mobile linear accelerator mounted on a robotic arm with an image-guided robotic system $[15,16,23,47]$. Patients are fixed in a thermoplastic mask and the treatment can be delivered as single-fraction or multi-fraction SRS. A variable number of overlapping beams (up to 200) are delivered nonisocentrically to the target, resulting in excellent dose coverage to the target and conformity. The set of beam directions and analysis of dose distribution are chosen through an inverse planning process. During the treatment, acquired oblique digital X-ray images of the patients are compared with digitally reconstructed radiographs (DRRs), which are obtained from planning CT images, and positioning errors corrected by translating and rotating the treatment table with an accuracy of less than $1 \mathrm{~mm}[15,16]$.

LINAC is the most frequently used device for delivery SRS in the world and uses multiple fixed fields or arcs shaped using a multileaf collimator with a leaf width of between 2.5 and $5 \mathrm{~mm}$ [17, 18, 48-51]. Dose conformity can be improved by the use of intensity modulation of the beams (IMRS) or volumetric modulated arc therapy (VMAT), resulting similar to that achieved with the GK and the CK. Patients are usually immobilized in a high precision frameless stereotactic mask fixation system with a reported accuracy of 1-2 $\mathrm{mm}$ [48]; however, technically most advanced LINACs offer improved accuracy of patient repositioning with the use of on-board imaging systems with either orthogonal $\mathrm{x}$-rays or cone beam CT (CBCT) that achieves an accuracy of less than 
$0.5-1 \mathrm{~mm}[17,18,50,51]$. The ExacTrac ${ }^{\circ} \mathrm{X}$. ray $6 \mathrm{D}$ system uses a combination of two main subsystems: an infrared-based system for initial patient setup and precise control of either translational or rotational couch movements, and a radiographic $\mathrm{kV} \mathrm{X}$-ray imaging system for position verification and readjustment based on internal anatomy. A CBCT system utilizes either the megavoltage radiation beam delivered from the LINAC or a kilovoltage beam delivered using an additional $\mathrm{x}$-ray tube mounted on the LINAC. During a single $360^{\circ}$ scan rotation, the system produces a series of twodimensional images of the entire volume of interest from multiple projection angles, which can be reconstructed in a three-dimensional data that can be directly compared with the CT planning study.

The superiority in terms of dose delivery and distribution for each of these techniques remains matter of debate. Despite several differences in treatments-related parameters among GK, CK and LINAC, there are no comparative studies demonstrating the clinical superiority of a technique over the others in terms of local control and radiation-induced toxicity for patients with brain tumors. Regardless of the technology used, a robust quality assurance (QA) program, encompassing all clinical, technical, and patient-specific treatment aspects, is mandatory to ensure the accuracy and safety of cranial SRS [52]. As stated by The World Health Organization, proper QA measures are imperative to reduce the likelihood of accidents and errors and increase the probability that the errors will be recognized and rectified if they do occur [52]. For brain SRS, detailed equipment specifications and tolerances, as well procedures that minimize the risk of errors and incidents have been reported by several professional organizations [52-57].

\section{Clinical results}

\section{Nonfunctioning pituitary adenomas}

SRS is frequently used in patients with residual or recurrent nonfunctioning pituitary adenoma. Data for 1965 patients with a nonfunctioning pituitary adenoma included in 23 studies published between 2002 and 2015 are shown in Table 1 [32, 58-78]. SRS was performed

Table 1 Selected published results of SRS (2000-2015) for the treatment of nonfunctioning pituitary adenomas

\begin{tabular}{|c|c|c|c|c|c|c|c|}
\hline \multirow[t]{2}{*}{ Authors } & \multirow[t]{2}{*}{ Patients } & \multirow{2}{*}{$\begin{array}{l}\text { Type } \\
\text { of SRS }\end{array}$} & \multirow{2}{*}{$\begin{array}{l}\text { dose } \\
\text { (Gy) }\end{array}$} & \multirow{2}{*}{$\begin{array}{l}\text { Follow-up } \\
\text { (months) }\end{array}$} & \multirow{2}{*}{$\begin{array}{l}\text { Tumor } \\
\text { control (\%) }\end{array}$} & \multicolumn{2}{|c|}{ Late toxicity (\%) } \\
\hline & & & & & & visual & hypopituitarism \\
\hline Feigl et al., 2002 [33] & 61 & GK & $15^{\mathrm{a}}$ & 55.2 & 94 & NA & 40 \\
\hline Sheehan et al., 2002 [58] & 42 & GK & $16^{a}$ & 31.2 & 97.6 & 2.4 & 0 \\
\hline Wowra \& Stummer, 2002 [59] & 30 & GK & $16^{\mathrm{a}}$ & 55 & 93.3 (93 at 5 years) & 0 & 10 \\
\hline Petrovich et al., 2003 [60] & 56 & GK & $15^{\mathrm{a}}$ & 36 & 100 & 3 & 4 \\
\hline Losa et al., 2004 [61] & 52 & GK & $16.6^{\mathrm{a}}$ & 41 & 96.3 (88.2 at 5 years) & 0 & 9.3 \\
\hline Muacevic et al., 2004 [62] & 51 & GK & $16.5^{\mathrm{a}}$ & 21.7 & 95 & 0 & 3.9 \\
\hline Picozzi et al., 2005 [63] & 51 & GK & $16.5^{\mathrm{a}}$ & 40.6 & 96.1 & NA & NA \\
\hline Iwai et al., 2005 [64] & 34 & GK & $12.3^{\mathrm{a}}$ & 59.8 & 87.1 (93 at 5 years) & 0 & 6.5 \\
\hline Mingione et al., 2006 [65] & 100 & GK & $18.5^{\mathrm{a}}$ & 44.9 & 92.2 & 0 & 19.7 \\
\hline Voges et al., 2006 [66] & 37 & LINAC & 13.4 & 56.6 & 100 & 1.4 & 12.3 \\
\hline Liscak et al., 2007 [67] & 140 & GK & $20^{a}$ & 60 & 100 & 0 & 2 \\
\hline Pollock et al., 2008 [68] & 62 & GK & $16^{\mathrm{a}}$ & 64 & 96.8 (95 at 5 years) & 0 & 27 \\
\hline Kobayashi et al., 2009 [69] & 71 & GK & $14.1^{\mathrm{a}}$ & 50.2 & 96.7 & 2.8 & 8.2 \\
\hline Hayashi et al., 2010 [70] & 43 & GK & $18.2^{\mathrm{a}}$ & 36 & 100 & 0 & 0 \\
\hline Gopalan et al., 2011 [71] & 48 & GK & $18.4^{\mathrm{a}}$ & 95 & 83.3 & 0 & 39 \\
\hline Iwata et al., 2011 [44] & 100 & CK & $3 \times 7 / 5 \times 5$ & 33 & 98 & 1 & 3 \\
\hline Park et al., 2011 [72] & 125 & GK & $13^{\mathrm{a}}$ & 62 & 90 (94 at 5 years) & 0,8 & 24 \\
\hline Starke et al., 2012 [73] & 140 & GK & $18^{\mathrm{a}}$ & 50 & 89.6 (97 at 5 years) & 0 & 30.3 \\
\hline Runge et al., 2012 [74] & 61 & LINAC & 13 & 83 & 98 & 0 & 9.8 \\
\hline Wilson et al., 2012 [75] & 51 & LINAC & 14 & 50 & 100 & 0 & 0 \\
\hline Sheehan et al., 2013 [76] & 512 & GK & $16^{\mathrm{a}}$ & 36 & 93.4 (95 at 5 years) & 7.9 & 21 \\
\hline Lee et al., 2014 [77] & 41 & GK & $12^{\mathrm{a}}$ & 48 & 92.7 (85 at 10 years) & 2.4 & 24.4 \\
\hline Bir et al., 2015 [78] & 57 & GK & $15^{\mathrm{a}}$ & 45.5 & 93 (90\% at 10 years) & 0 & 8.8 \\
\hline
\end{tabular}

SRS stereotactic radiosurgery, GK Gamma Knife, LINAC Linear Accelerator, CK CyberKnife, NA not assessed 
with GK in 19 studies, LINAC in 3 studies, and CK in one study. With a median follow-up ranging from 21.7 months to 95 months (average 47.3 months), tumor control was seen in $94 \%$ of patients using a median prescription dose of 16 Gy (range 12-20 Gy). In 9 studies including 1053 patients with nonfunctioning pituitary adenoma, 5-year Kaplan-Meier local control estimate was $92 \%[59,61,64,68,72,73,76-78]$ (Table 1). A decrease in tumor size has been reported in $20-60 \%$ of patients. With regard to factors predicting local control after SRS, smaller tumor volumes $\left(<5 \mathrm{~cm}^{3}\right)$ and limited suprasellar extension were associated with improved local control [68, 72, 73, 76].

There is no consensus about the timing of SRS for nonfunctioning pituitary adenomas. Early postoperative SRS treatment has been suggested by some authors to decrease the rate of tumor progression and symptomatic endocrinophaty of subtotally resected nonfunctioning pituitary adenomas as compared with late SRS $[63,79]$; in contrast, a policy of surveillance may be observed in older patients with small residual tumors for the low incidence of symtomatic recurrences following subtotal tumor resection [80].

New or worsened hormone pituitary deficits were the most common complication after SRS, with a median incidence of hypopituitarism of $18 \%$ at median follow-up of 47 months [32, 58-78] (Table 1); neurological complications, including worsening of vision or other cranial nerve deficits, were less common (average $2.4 \%$, range 0-7.9\%).

Radiation doses used for patients with nonfunctioning adenomas treated with SRS are shown in Table 1. Median dose prescription was 12-14 Gy in 6 studies [64, $66,72,74,75,77], 14.1-16$ Gy in 8 studies [32, 58, 59, $68,69,76,78]$, and $>16$ Gy in 7 studies $[61-63,65,67$, $70,71,73$ ] including 349, 891, and 625 patients, respectively. Median tumor control rates were $93 \%$ for doses of 12-14 Gy (median follow-up 61 months), $95 \%$ for doses of 14.1-16 Gy (median follow-up 41 months), and $94 \%$ for doses $>16$ Gy (median follow-up 50 months). In a retrospective multicenter clinical trial of 512 patients treated with GK SRS, Sheehan et al [76] showed that margin doses $<12$ Gy were significantly associated with worse control rate as compared with doses of 12-20 Gy, whereas no significant difference in tumor control rates have been observed between patients treated with $12-$ 20 Gy versus those receiving doses $>20$ Gy. Similar results have been reported by others $[65,71-73,76]$.

Multi-fraction SRS (2-5 fractions) has been employed in patients with tumors involving the optic apparatus who are considered not suitable for SRS [44, 81-83]. Using doses of 18-24 Gy delivered in two to five sessions with Cyberknife, Adler et al. [81] reported a tumor control of $94 \%$ in 46 patients with a pituitary adenoma or meningioma within $2 \mathrm{~mm}$ of the optic apparatus at a median follow-up of 49 months. A case of radiation optic neuropathy was observed in one patient who had a previous course of conventional RT. Iwata et al. [44] reported a local control rate of $98 \%$ at 3 years in 100 patients with nonfunctioning pituitary adenomas treated with CK SRS using doses of 21 in 3 fractions or 25 Gy in 5 fractions. Complications were represented by grade 2 visual disorders in one patient and new onset of hypopituitarism in 4 patients. Similar tumor control and low toxicity have been reported in other few series $[45,82,83]$.

\section{GH-secreting pituitary adenomas}

SRS is commonly used in patients with a GH-secreting pituitary adenoma failing surgery and/or resistant to medical therapy. Data from 32 studies on SRS including 1802 patients with $\mathrm{GH}$-secreting pituitary adenomas show median weighted tumor control and biochemical control of disease rates of $95 \%$ and $44 \%$, respectively, at a median follow-up of 59 months (Table 2) [36, 37, 66, 70, 82, 84-110]. GK SRS is the most used technique, with a reported biochemical remission of $46 \%$ at a median follow-up of 58 months. Four studies report results of LINAC SRS, 2 studies report results of proton SRS, and one study report results of CK SRS for GHsecreting tumors, showing a biochemical remission of disease ranging from 19 to $68 \%$ at a median follow-up of 62 months.

The variable rate of hormone normalization observed in the different series may depend, at least in part, by different criteria used to define GH/IFG-1 plasma levels normalization, different follow-up times, pre-irradiation GH/IGF-1 levels and concomitant medical therapies, making difficult the interpretation of published results and the real efficacy of SRS. Nevertheless, using stringent criteria of cure, as defined by suppressed GH levels $<1 \mathrm{ng} / \mathrm{ml}$ during an oral glucose tolerance test (OGTT) and normal age-corrected IGF-1 levels, the KaplanMeier estimate of local control reported in 10 studies including 700 patients was $52 \%$ at 5 years $[66,91,93,94$, 96, 97, 99, 103, 108, 109] (Table 2), and normalization of GH/IGF-1 levels continued throughout the follow-up period.

A variable median dose prescription of 14 to 31 Gy has been used in the published series $[36,37,66,70,82$, 84-110] (Table 2). Median doses were $<20$ Gy in 4 studies [66, 87, 90, 105], 20-25 Gy in 21 studies $[85,8689,92,93,95-99,102-104,106-110]$, and $>25$ Gy in 6 studies $[84,88,91,94,100,101]$ that include 216, 1196 , and 390 patients, respectively (Table 2). Biochemical remission was $31 \%$ for doses $<20$ Gy (median follow-up 55 months), $47 \%$ for doses of 20-25 Gy 
Table 2 Selected published results of SRS (2000-2015) for the treatment of GH-secreting pituitary adenomas

\begin{tabular}{|c|c|c|c|c|c|c|c|c|}
\hline \multirow[t]{2}{*}{ Authors } & \multirow[t]{2}{*}{ Patients } & \multirow{2}{*}{$\begin{array}{l}\text { Type } \\
\text { of SRS }\end{array}$} & \multirow{2}{*}{$\begin{array}{l}\text { Dose } \\
\text { (Gy) }\end{array}$} & \multirow{2}{*}{$\begin{array}{l}\text { Follow-up } \\
\text { (months) }\end{array}$} & \multirow{2}{*}{$\begin{array}{l}\text { Tumor } \\
\text { control (\%) }\end{array}$} & \multirow{2}{*}{$\begin{array}{l}\text { Biochemical } \\
\text { remission (\%) }\end{array}$} & \multicolumn{2}{|c|}{ Late toxicity (\%) } \\
\hline & & & & & & & visual & hypopituitarism \\
\hline Zhang et al., 2000 [84] & 68 & GK & $31^{\mathrm{a}}$ & 34 & 100 & 40 & NA & NA \\
\hline Izawa et al., 2000 [85] & 29 & GK & $22.5^{\mathrm{a}}$ & 26.4 & 93 & 41 & 0 & 0 \\
\hline Attanasio et al., 2003 [86] & 30 & GK & $20^{a}$ & 46 & 100 & 23 & 0 & 6.3 \\
\hline Jane et al., 2003 [87] & 64 & GK & $15^{\mathrm{a}}$ & $>18$ & 100 & 36 & 0 & 28 \\
\hline Castinetti et al., 2005 [88] & 82 & GK & $28.5^{\mathrm{a}}$ & 49.5 & 100 & 17 & 1.2 & 16 \\
\hline Gutt et al., 2005 [89] & 44 & GK & $23^{\mathrm{a}}$ & 23 & 100 & 48 & 0 & NA \\
\hline Kobayashi et al., 2005 [90] & 67 & GK & $18.9^{\mathrm{a}}$ & 63.3 & 100 & 17 & 11.1 & 14.6 \\
\hline Jezkova et al., 2006 [91] & 96 & GK & $35^{\mathrm{a}}$ & 53.7 & 100 & 50 (44 at 5 years) & 0 & 27.1 \\
\hline Voges et al., 2006 [66] & 64 & LINAC & 16.5 & 54.3 & 97 & 37.5 (33 at 5 years) & 1,4 & 12.3 (18 at 5 years) \\
\hline Petit et al., 2007 [92] & 22 & Protons & 20 & 75 & 95 & 59 & 0 & 38 \\
\hline Pollock et al., 2007 [93] & 46 & GK & $20^{a}$ & 63 & 100 & 50 (60 at 5 years) & 2.2 & 36 \\
\hline Roberts et al., 2007 [82] & 9 & CK & $18-24^{\mathrm{a}}$ & 25.4 & 100 & 44.4 & 0 & 33 \\
\hline Vik-Mo et al., 2007 [94] & 61 & GK & $26.5^{\mathrm{a}}$ & 66 & 100 & 38 (58 at 5 years) & 0 & 23 \\
\hline Jagannathan et al., 2008 [95] & 95 & GK & $22^{\mathrm{a}}$ & 57 & 98 & 53 & 4.2 & 34 \\
\hline Losa et al., 2008 [96] & 83 & GK & $21.5^{\mathrm{a}}$ & 69 & 97.6 & 60 (52 at 5 years) & 0 & 8.5 (11.8 at 5 years) \\
\hline Ronchi et al., 2009 [97] & 35 & GK & $20^{\mathrm{a}}$ & 114 & 100 & 82 (46 at 10 years) & 0 & 50 \\
\hline Wan et al., 2009 [98] & 103 & GK & $21.4^{\mathrm{a}}$ & 67.3 & 95.1 & 36.9 & NA & 1.7 \\
\hline Hayashi et al., 2010 [70] & 25 & GK & $25^{\mathrm{a}}$ & 36 & 100 & 40 & 0 & 0 \\
\hline Iwai et al., 2010 [99] & 26 & GK & $20^{\mathrm{a}}$ & 84 & 96 & 38 (17 at 5 years) & 0 & 8 \\
\hline Castinetti et al., 2009 [100] & 43 & GK & $26^{a}$ & 96 & 100 & 42,0 & 0 & 23 \\
\hline Poon et al., 2010 [101] & 40 & GK & $29^{a}$ & 73.8 & NA & 17 & 0 & 11.4 \\
\hline Erdur et al., 2011 [102] & 22 & GK & $23.8^{\mathrm{a}}$ & 60 & 95,2 & 54,5 & 0 & 28.6 \\
\hline Sheehan et al., 2011 [36] & 130 & GK & $24^{\mathrm{a}}$ & 31 & 93 & 53 & 2.3 & 34 \\
\hline Sicignano et al., 2012 [37] & 39 & GK & $25^{\mathrm{a}}$ & 60 & 97.7 & 54 & NA & 12.3 \\
\hline Franzin et al., 2012 [103] & 103 & GK & $22.5^{\mathrm{a}}$ & 71 & 97,3 & 60.7 (57 at 5 years) & 0 & 7.8 \\
\hline Liu et al., 2012 [104] & 40 & GK & $21^{a}$ & 72 & 97,5 & 47,5 & 0 & 40 \\
\hline Zeiler et al., 2013 [105] & 21 & GK & $14.2^{\mathrm{a}}$ & 33 & 100 & 30 & 3.9 & 13.2 \\
\hline Yan et al., 2013 [106] & 22 & LINAC & 23 & 98 & 95 & 68.2 & 0 & 22.7 \\
\hline Wilson et al., 2013 [107] & 86 & LINAC & 20 & 66 & 96 & 18.6 & 1,2 & 19.8 \\
\hline Lee et al., 2014 [108] & 136 & GK & $25^{\mathrm{a}}$ & 61.5 & 98.5 & 65.4 (73.4 at 6 years) & 3.7 & 31.6 \\
\hline Wattson et al., 2014 [109] & 50 & Protons & 20 & 51.5 & 100 & 48 (49 at 5 years) & 0 & 57 (62 at 5 years) \\
\hline Bostrom et al., 2015 [110] & 21 & LINAC & 20 & 96 & 97.1 & 23 & 5 & 46.4 \\
\hline
\end{tabular}

SRS stereotactic radiosurgery, GK Gamma Knife, LINAC Linear Accelerator, CK CyberKnife, NA not assessed

amarginal dose; $\wedge 1-3$ fractions

(median follow-up 60 months), and $33 \%$ for doses > 25 Gy (median follow-up 59 months).

Although early reports suggest that the decline in $\mathrm{GH}$ levels after GK SRS is faster compared with fractionated RT $[111,112]$, the rate of decline observed in most recent series is similar to that reported following fractionated RT [86, 91, 93, 96, 100, 103]. The rate of decline mainly depends on pretreatment levels of GH and IGF-1 levels. Losa et al. [96] reported a median time for remission of 37 months for patients with pretreatment $\mathrm{GH}$ levels $\leq 7 \mu \mathrm{g}$ /liter as compared with 93 months for patients with $\mathrm{GH}$ levels $>7 \mu \mathrm{g} /$ liter. In another retrospective analysis of 46 patients, the 5-year biochemical remission rates $90 \%$ for patients with IGF-1 levels less than 2.25 times the upper limit of normal and $38 \%$ for those with IGF-1 levels greater than 2.25 times the upper limit of normal, respectively [93].

\section{Cushing disease}

SRS data for 706 patients with Cushing's disease included in 21 studies are shown in Table 3 [35, 37, 66, 69, 70, 92, 98, 105, 109, 113-123]. Biochemical remission of 
Table 3 Selected published results of SRS (2000-2015) for the treatment of ATCH-secreting pituitary adenomas

\begin{tabular}{|c|c|c|c|c|c|c|c|c|}
\hline \multirow[t]{2}{*}{ Authors } & \multirow[t]{2}{*}{ Patients } & \multirow{2}{*}{$\begin{array}{l}\text { Type } \\
\text { of SRS }\end{array}$} & \multirow{2}{*}{$\begin{array}{l}\text { dose } \\
\text { (Gy) }\end{array}$} & \multirow{2}{*}{$\begin{array}{l}\text { Follow-up } \\
\text { (months) }\end{array}$} & \multirow{2}{*}{$\begin{array}{l}\text { Tumor } \\
\text { control (\%) }\end{array}$} & \multirow{2}{*}{$\begin{array}{l}\text { Biochemical } \\
\text { remission (\%) }\end{array}$} & \multicolumn{2}{|c|}{ Late toxicity (\%) } \\
\hline & & & & & & & visual & hypopituitarism \\
\hline Izawa et al., 2000 [85] & 12 & GK & $23.8^{\mathrm{a}}$ & 26.4 & 100 & 17 & NA & 0 \\
\hline Sheehan et al., 2000 [113] & 43 & GK & $20^{\mathrm{a}}$ & 44 & 100 & 63 & 2 & 16 \\
\hline Hoybye et al., 2001 [114] & 18 & GK & $>25^{\mathrm{a}}$ & 17 years & 100 & 83 & 0 & 66 \\
\hline Devin et al., 2004 [115] & 35 & LINAC & 14.7 & 35 & 91 & 49 & 0 & 40 \\
\hline Voges et al., 2006 [66] & 17 & LINAC & 16.4 & 58.7 & 82.4 & 52.9 & 1.4 & 12.3 \\
\hline Castinetti et al., 2007 [116] & 40 & GK & $29.5^{\mathrm{a}}$ & 54.7 & 100 & 42.5 & 2.5 & 15 \\
\hline Jagannathan et al., 2007 [117] & 90 & GK & $25^{\mathrm{a}}$ & 45 & 96 & 54 & 5.5 & 22 \\
\hline Petit et al., 2007 [92] & 33 & Protons & 20 & 62 & 94 & 52 & 0 & 52 \\
\hline Pollock et al., 2008 [118] & 8 & GK & $18^{\mathrm{a}}$ & 54 & 100 & 87 & 0 & 36 \\
\hline Tinnel et al., 2008 [119] & 12 & GK & $25^{\mathrm{a}}$ & 37 & 83.3 & 50 & 0 & 50 \\
\hline Wan et al., 2009 [98] & 68 & GK & $23^{\mathrm{a}}$ & 67.3 & 89.7 & 27.9 & 2.9 & 1.7 \\
\hline Kobayashi et al., 2009 [120] & 30 & GK & $28.7^{\mathrm{a}}$ & 64.1 & 100 & 35 & NA & NA \\
\hline Hayashi et al., 2010 [70] & 13 & GK & $25.2^{\mathrm{a}}$ & 36 & 97 & 38 & 15.4 & 0 \\
\hline Sicignano et al., 2012 [37] & 15 & GK & $23.8^{\mathrm{a}}$ & 60 & 97.7 & 64 & NA & 12.3 \\
\hline Wein et al., 2012 [120] & 17 & LINAC & 18 & 23 & 94.1 & 58.8 & 0 & 11.8 \\
\hline Zeiler et al., 2013 [105] & 8 & GK & $24.7^{a}$ & 35 & 100 & 50 & 3.9 & 13.2 \\
\hline Grant et al., 2013 [121] & 15 & GK & $35^{\mathrm{a}}$ & 40.2 & 100 & 73 & 3.2 & 32 \\
\hline Sheehan et al., 2013 [122] & 96 & GK & $22^{\mathrm{a}}$ & 48 & 98 & 70 & 5 & 36 \\
\hline Wattson et al., 2014 [109] & 74 & Protons & 20 & 47 & 98.6 & 67 at 5 years & 0 & 62 at 5 years \\
\hline Wilson et al., 2014 [123] & 36 & LINAC & 20 & 66 & 97 & 25 & 0 & 13.9 \\
\hline Marek et al., 2015 [35] & 26 & GK & $29^{\mathrm{a}}$ & 78 & 91.9 & 80.7 & 0 & 11.5 \\
\hline
\end{tabular}

SRS stereotactic radiosurgery, GK Gamma Knife, LINAC Linear Accelerator, CK CyberKnife, NA not assessed

amarginal dose

disease was reported from $25 \%$ to $80.7 \%$ of patients at a variable median follow-up of 2 to 17 years, with median tumor control rates ranging from $87 \%$ to $100 \%$. At a weighted average follow-up of 56 months, the median tumor control was $95 \%$ and biochemical remission of disease, as measured by normalization of $24 \mathrm{~h}$ urinary free cortisol (UFC) and/or plasma cortisol levels, was $48 \%$.

The median time to hormone normalization ranges from 12 to 25 months $[35,115,116,122]$. In a retrospective series of 96 patients with Cushing's disease treated by GK SRS at the University of Virginia, Sheehan et al. [122] reported a tumor control and biochemical remission rates of $98 \%$ and $70 \%$, respectively, with a time to normalization of 16.6 months. New or worsened hypopituitarism occurred in $36 \%$ of patients and progressive or new onset optic neuropathy occurred in $4.5 \%$ of patients. In another series of 40 patients with Cushing's disease treated by GK SRS, Castinetti et al. [116] reported the biochemical remission of disease in $42.5 \%$ of patients at a mean follow-up of 54 months, with a mean time to hormone normalization of 22 months. Similar remission rates have been shown in other retrospective series $[35,115,122]$ (Table 3). A recurrence rate up to $20 \%$ after an initial remission of disease has been reported in some series $[115,116,122$, 123], indicating that a careful follow-up is mandatory also in patients who achieve normal hormone levels.

A median prescription dose of $<20$ Gy has been used in 4 studies including 77 patients $[66,115,118,120]$, of 20 to 25 Gy in 11 studies including 487 patients [37, 85, 92, 98, 105, 109, 113, 117, 119, 122, 123], and > 25 Gy in 6 studies including 142 patients [35, 70, 114, 116, 121] (Table 3). The reported biochemical remission of disease was similar, being $53 \%$ for doses $<20$ Gy (median follow-up 40 months), $54 \%$ for doses of 20-25 Gy (median follow-up 46 months), and $47 \%$ for doses $>25$ Gy (median follow-up 62 months), and with respective tumor control of $90 \%, 98 \%$, and $95 \%$; however, in a few studies a higher margin radiation dose of 25 Gy was significantly associated with better biochemical remission of disease [117].

\section{Prolactinomas}

SRS is usually reserved for prolactinomas resistant to medical therapy with dopamine agonists. Data for 610 patients with a prolactin-secreting pituitary adenoma included in 17 studies published between 2000 and 2015 
are shown in Table $4[32,36,60,66,85,98,100,109$, $118,124-131]$. SRS was performed with GK in 15 studies, with LINAC in one study, and with protons in one study. With a median follow-up ranging from 25 months to 75.5 months (average 49 months), tumor control and biochemical remission rates were reported for $95 \%$ and $44 \%$ of patients using median doses of 15 to $33 \mathrm{~Gy}$.

The rate of normalization of prolactin levels was similar for patients treated with doses $<20$ Gy $(5$ studies, 86 patients) [32, 60, 118, 127, 130], 20-25 Gy (7 studies, 305 patients) [36, 66, 85, 98, 109, 129, 131], and $>25$ Gy (5 studies, 219 patients) [100, 124-126, 128] (Table 4). With median follow-ups of 50, 61, and 70 months, biochemical remission rates were $40 \%, 23 \%$, and $38 \%$ for doses $<20$ Gy, 20-25 Gy, and $>25$ Gy, respectively.

\section{Complications}

Based on the available published series, the overall rate of serious complications after SRS is low. The mainly reported complication is the development of hypopituitarism, with 5-year incidence of new or worsening pituitary deficits of $24 \%$ (range from 10 to $40 \%$ ) [34, 61, 64, 66, 68, 72-78, 91, 93-97, 99, 103, 108, 109, 116, 118, 127, 129]. Rates of hypopituitarism are similar among nonfunctioning and secreting pituitary adenomas. Factors related to higher risk of hypopituitarism include preexisting anterior pituitary deficits, larger tumor volumes, higher doses delivered to the pituitary gland and to the pituitary stalk, and longer follow-up [34-37]. However, hypopituitarism can be effectively managed with hormonal replacement, and significant reduction of the prescribed dose to prevent hypopituitarism with the risk of compromising effectiveness of treatment in terms of local control and normalization of hormonal hypersecretion is not recommended. The risk of radiation-induced optic neuropathy is $0-3 \%$ for single point doses less than 8-10 Gy to the optic apparatus [24-30]. Neuropathy of cranial nerves III-VI and radiation-induced brain necrosis have been reported in less than $2 \%$ of patients, with higher risk for those who received previous conventional radiotherapy. The risk to develop a second brain tumor after SRS appears to be significantly less than that seen following conventional RT [11]; however the relatively short length of follow-up in several published series $(<5$ years) does not allow for any definitive conclusion.

\section{Conclusions}

SRS is an effective treatment modality for patients with pituitary adenomas after unsuccessful surgery and/or resistant to medical therapy. Doses of 13-16 Gy are usually employed for nonfunctioning pituitary adenomas with a reported tumor control of $85-95 \%$ at 5-10 years, whereas higher doses are commonly used for hormonally active pituitary adenomas. For secreting adenomas, normalization of hormone hypersecretion is reported in

Table 4 Selected published results of SRS (2000-2015) for the treatment of prolactin-secreting pituitary adenomas

\begin{tabular}{|c|c|c|c|c|c|c|c|c|}
\hline \multirow[t]{2}{*}{ Authors } & \multirow[t]{2}{*}{ Patients } & \multirow{2}{*}{$\begin{array}{l}\text { Type } \\
\text { of SRS }\end{array}$} & \multirow{2}{*}{$\begin{array}{l}\text { dose } \\
\text { (Gy) }\end{array}$} & \multirow{2}{*}{$\begin{array}{l}\text { Follow-up } \\
\text { (months) }\end{array}$} & \multirow{2}{*}{$\begin{array}{l}\text { Tumor } \\
\text { control (\%) }\end{array}$} & \multirow{2}{*}{$\begin{array}{l}\text { Biochemical } \\
\text { remission (\%) }\end{array}$} & \multicolumn{2}{|c|}{ Late toxicity (\%) } \\
\hline & & & & & & & visual & hypopituitarism \\
\hline Landolt 2000 [124] & 20 & GK & 29 & 25 & 85 & 25 & 0 & NA \\
\hline Pan L et al., 2000 [125] & 128 & GK & 33 & 41 & 99 & 41 & 0 & NA \\
\hline Izawa et al., 2000 [85] & 15 & GK & 23.6 & 16 & 100 & 16 & 0 & NA \\
\hline Feigl et al., 2002 [32] & 18 & GK & $15^{\mathrm{a}}$ & 55 & 94 & 60 & NA & 40 \\
\hline Choi et al., 2003 [126] & 21 & GK & $28.5^{\mathrm{a}}$ & 42.5 & 96.9 & 23.8 & 0 & 0 \\
\hline Petrovich et al., 2003 [60] & 12 & GK & $15^{\mathrm{a}}$ & 41 & 83 & 83 & 0 & 4 \\
\hline Pouratian et al., 2006 [127] & 23 & GK & $18.6^{\mathrm{a}}$ & 55 & 89 & 26 & 7 & 28 \\
\hline Voges et al., 2006 [66] & 13 & LINAC & 20 & 56 & 100 & 15.4 & 4.2 & 18.3 \\
\hline Pollock et al., 2008 [118] & 11 & GK & $18^{\mathrm{a}}$ & 48 & 100 & 18 at 4 years & 9.1 & 36 \\
\hline Castinetti et al., 2009 [100] & 15 & GK & $28^{\mathrm{a}}$ & 96 & 100 & 46.6 & 0 & 21 \\
\hline Jezkova et al., 2009 [128] & 35 & GK & $34^{a}$ & 75.5 & 97 & 37.1 & 0 & 14.3 \\
\hline Wan et al., 2009 [98] & 176 & GK & $22.4^{a}$ & 67.5 & 90.3 & 23.3 & 0 & 1.8 \\
\hline Tanaka et al., 2010 [129] & 22 & GK & $25^{\mathrm{a}}$ & 60 & 100 & 18 & 4 & 42 at 4 years \\
\hline Sheehan et al., 2011 [36] & 32 & GK & $24^{a}$ & 31 & 93 & 26 & 2.4 & 24.4 \\
\hline Liu et al., 2013 [130] & 22 & GK & $15^{\mathrm{a}}$ & 36 & 86 & 27.3 & 0 & 4.5 \\
\hline Wattson et al., 2014 [109] & 9 & Protons & 20 & 60 & 98 & 22 & 0 & 57 \\
\hline Cohen-Inbar et al., 2015 [131] & 38 & GK & $25^{\mathrm{a}}$ & 42.3 & 92 & 50 & 4.2 & 30.3 \\
\hline
\end{tabular}

SRS stereotactic radiosurgery, GK Gamma Knife, LINAC Linear Accelerator, CK CyberKnife, NA not assessed 
more than $50 \%$ of patients at 5 years, being similar for doses of 20-25 Gy or $>25$ Gy. Currently, the optimal dose to achieve biochemical remission of hormonesecreting adenomas remains to be determined. The majority of studies report on the use of GK SRS in patients with either nonfunctioning or secreting pituitary adenomas, whereas only few retrospective series show the results of LINAC SRS. In the respect of few series, the reported tumor control, biochemical remission of disease, and toxicity so far are broadly equivalent.

Hypopituitarism represents the most commonly reported late complication of treatment, whereas the incidence of other late effect radiation complications are low. In this regard, an accurate delineation of the target and surrounding structures is mandatory during the radiosurgical process; future studies need to incorporate precise dosimetric information of doses delivered to OARs to better understand the relationship between doses to OARs and development of hypopituitarism.

A few series suggest that multi-fraction SRS may be an appropriate treatment in patients with tumors in close proximity to the optic apparatus; however, the advantages of hypofractionated schedules in terms of local control and risk of radiation-induced toxicity as compared to single-fraction SRS remains to be proved. For large pituitary adenomas involving the optic apparatus, the use of fractionated stereotactic radiotherapy using a conventional fractionation (45-54 Gy in 25-30 daily fractions) is recommended. Several studies have shown a tumor control of 90-95\% for pituitary tumors of any size, including large or giant tumors, and hormone hypersecretion normalization of $50 \%$ at 5 years [132-142].

In clinical practice, single fraction SRS is recommended for small-to-moderate sized pituitary adenomas $(<2.5-3 \mathrm{~cm})$ even when the adenoma is close to the optic apparatus as long as the dose to the optic apparatus is kept below 8-10 Gy. Fractionated SRS, usually 25 Gy in 5 fractions, may represent a better treatment option when a single fraction dose carries an unacceptable risk of optic neuropathy (as for tumors adiacent the optic chiasm); however, studies with more patients and longer follow-up are required to draw definite conclusions. Fractionated stereotactic radiotherapy would be the recommended radiation treatment modality for lesions $>3 \mathrm{~cm}$ in size and/or compressing the anterior visual pathway.

\section{Acknowledgements}

Not applicable.

\section{Funding}

This research received no funding.

Availability of data and materials

Data sharing not applicable to this article as no datasets were generated or analysed during the current study.
Authors' contributions

GM, MO and MN participated in article preparation, data analysis and wrote the manuscript. All authors have approved the final article.

\section{Competing interests}

The authors declare that they have no competing interests.

\section{Consent for publication}

Not applicable.

Ethics approval and consent to participate

Not applicable.

\section{Author details}

'Unit of Radiation Oncology, Sant' Andrea Hospital, University Sapienza, Rome, Italy. ${ }^{2}$ IRCCS Neuromed, Pozzilli (IS), Italy. ${ }^{3}$ Department of Radiation Oncology, LMU Munich, Munich, Germany.

Received: 10 July 2016 Accepted: 1 October 2016

Published online: 11 October 2016

\section{References}

1. McCollough WM, Marcus Jr RB, Rhoton Jr AL, Ballinger WE, Million RR. Longterm follow-up of radiotherapy for pituitary adenoma: the absence of late recurrence after greater than or equal to 4500 cGy. Int J Radiat Oncol Biol Phys. 1991;21:607-14.

2. Brada M, Rajan B, Traish D, Ashley S, Holmes-Sellors PJ, Nussey S, et al. The long-term efficacy of conservative surgery and radiotherapy in the control of pituitary adenomas. Clin Endocrinol (Oxf). 1993;38:571-8.

3. Tsang RW, Brierly JD, Panzarella T, Gospodarowicz MK, Sutcliffe SB, Simpson WJ. Radiation therapy for pituitary adenoma: treatment outcome and prognostic factors. Int J Radiat Oncol Biol Phys. 1994;30:557-65.

4. Zierhut D, Flentje M, Adolph J, Erdmann J, Raue F, Wannenmacher M. External radiotherapy of pituitary adenomas. Int J Radiat Oncol Biol Phys. 1995:33:307-14.

5. Estrada J, Boronat M, Mielgo M, Magallon R, Millan I, Diez S, et al. The longterm outcome of pituitary irradiation after unsuccessful transsphenoidal surgery in Cushing's disease. N Engl J Med. 1997;336:172-7.

6. Barrande G, Pittino-Lungo M, Coste J, Ponvert D, Bertagna X, Luton JP, et al. Hormonal and metabolic effects of radiotherapy in acromegaly: long-term results in 128 patients followed in a single center. J Clin Endocrinol Metab. 2000;85:3779-85.

7. Minniti G, Jaffrain-Rea ML, Osti M, Esposito V, Santoro A, Solda F, et al. The long-term efficacy of conventional radiotherapy in patients with $\mathrm{GH}$ secreting pituitary adenomas. Clin Endocrinol (Oxf). 2005;62:210-6.

8. Minniti G, Osti M, Jaffrain-Rea ML, Esposito V, Cantore G, Maurizi ER. Longterm follow-up results of postoperative radiation therapy for Cushing's disease. J Neurooncol. 2007:84:79-84.

9. McCord MW, Buatti JM, Fennell EM, Mendenhall WM, Marcus Jr RB, et al. Radiotherapy for pituitary adenoma: long-term outcome and sequelae. Int J Radiat Oncol Biol Phys. 1997;39:437-44.

10. Brada M, Asley S, Ford D, Traish D, Burchell L, Rahan B. Cerebrovascular mortality in patients with pituitary adenoma. Clin Endocrinol. 2002;57:713-7.

11. Minniti G, Traish D, Ashley S, Gonsalves A, Brada M. Risk of second brain tumor after conservative surgery and radiotherapy for pituitary adenoma: update after an additional 10 years. J Clin Endocrinol Metab. 2005;90:800-4.

12. Noad R, Narayanan KR, Howlett T, Lincoln NB, Page RC. Evaluation of the effect of radiotherapy for pituitary tumours on cognitive function and quality of life. Clin Oncol (R Coll Radiol). 2004;16:233-7.

13. Amichetti M, Amelio D, Minniti G. Radiosurgery with photons or protons for benign and malignant tumours of the skull base: a review. Radiat Oncol. 2012;7:210.

14. Wu A, Lindner G, Maitz AH, Kalend AM, Lunsford LD, Flickinger JC, Bloomer WD. Physics of gamma knife approach on convergent beams in stereotactic radiosurgery. Int J Radiat Oncol Biol Phys. 1990;18:941-9.

15. Yu C, Jozsef G, Apuzzo ML, Petrovich Z. Dosimetric comparison of Cyberknife with other radiosurgical modalities for an ellipsoidal target. Neurosurgery. 2003;53:1155-62

16. Kuo JS, Yu C, Petrovich Z, Apuzzo ML. The CyberKnife stereotactic radiosurgery system: description, installation, and an initial evaluation of use and functionality. Neurosurgery. 2008;62 Suppl 2:785-9. 
17. Ramakrishna N, Rosca F, Friesen S, Tezcanli E, Zygmanszki P, Hacker F. A clinical comparison of patient setup and intra-fraction motion using frame based radiosurgery versus a frameless image-guided radiosurgery system for intracranial lesions. Radiother Oncol. 2010;95:109-15.

18. Gevaert T, Verellen D, Tournel K, Linthout N, Bral S, Engels B, et al. Setup accuracy of the Novalis ExacTrac 6DOF system for frameless radiosurgery. Int J Radiat Oncol Biol Phys. 2012;82:1627-35.

19. Minniti G, Gilbert DC, Brada M. Modern techniques for pituitary radiotherapy. Rev Endocr Metab Disord. 2009;10:135-44.

20. Morana G, Maghnie M, Rossi A. Pituitary tumors: advances in neuroimaging. Endocr Dev. 2010;17:160-74.

21. Guckenberger M, Baier K, Guenther I, Richter A, Wilbert J, Sauer O, et al. Reliability of the bony anatomy in image-guided stereotactic radiotherapy of brain metastases. Int J Radiat Oncol Biol Phys. 2007;69:294-301.

22. Heck B, Jess-Hempen A, Kreiner HJ, Schöpgens H, Mack A. Accuracy and stability of positioning in radiosurgery: long-term results of the Gamma Knife system. Med Phys. 2007;34:1487-95.

23. Chang SD, Main W, Martin DP, Gibbs IC, Heilbrun MP. An analysis of theaccuracy of the Cyberknife: a robotic frameless stereotactic radiosurgical system. Neurosurgery. 2003;52:140-6.

24. Tishler RB, Loeffler JS, Lunsford LD, Duma C, Alexander 3rd E, Kooy HM, et al. Tolerance of cranial nerves of the cavernous sinus to radiosurgery. Int J Radiat Oncol Biol Phys. 1993;27:215-21.

25. Leber KA, Berglöff J, Pendl G. Dose-response tolerance of the visual pathways and cranial nerves of the cavernous sinus to stereotactic radiosurgery. J Neurosurg. 1998;88:43-50.

26. Stafford SL, Pollock BE, Leavitt JA, Foote RL, Brown PD, Link MJ, et al. A study on the radiation tolerance of the optic nerves and chiasm after stereotactic radiosurgery. Int J Radiat Oncol Biol Phys. 2003;55:1177-81.

27. Hasegawa T, Kobayashi T, Kida Y. Tolerance of the optic apparatus in singlefraction irradiation using stereotactic radiosurgery: evaluation in 100 patients with craniopharyngioma. Neurosurgery. 2010;66:688-94.

28. Mayo C, Martel MK, Marks LB, Flickinger J, Nam J, Kirkpatrick J. Radiation dose-volume effects of optic nerves and chiasm. Int J Radiat Oncol Biol Phys. 2010;76(3 Suppl):S28-35.

29. Leavitt JA, Stafford SL, Link MJ, Pollock BE. Long-term evaluation of radiation-induced optic neuropathy after single-fraction stereotactic radiosurgery. Int J Radiat Oncol Biol Phys. 2013;87:524-7.

30. Pollock BE, Link MJ, Leavitt JA, Stafford SL. Dose-volume analysis of radiation-induced optic neuropathy after single-fraction stereotactic radiosurgery. Neurosurgery. 2014;75:456-60.

31. Hiniker SM, Modlin LA, Choi CY, Atalar B, Seiger K, Binkley MS, et al. DoseResponse Modeling of the Visual Pathway Tolerance to Single-Fraction and Hypofractionated Stereotactic Radiosurgery. Semin Radiat Oncol. 2016;26:97-104.

32. Roche PH, Régis J, Dufour H, Fournier HD, Delsanti C, Pellet W, et al. Gamma knife radiosurgery in the management of cavernous sinus meningiomas. J Neurosurg. 2000;93(Suppl):68-73.

33. Feigl GC, Bonelli CM, Berghold A, Mokry M. Effects of gamma knife radiosurgery of pituitary adenomas on pituitary function. J Neurosurg. 2002; 97(5Suppl):415-21.

34. Vladyka V, Liscák R, Novotný Jr J, Marek J, Jezková J. Radiation tolerance of functioning pituitary tissue in gamma knife surgery for pituitary adenomas. Neurosurgery. 2003;52:309-16.

35. Leenstra JL, Tanaka S, Kline RW, Brown PD, Link MJ, Nippoldt TB, et al. Factors associated with endocrine deficits after stereotactic radiosurgery of pituitary adenomas. Neurosurgery. 2010;67:27-32.

36. Marek J, Jezková J, Hána V, Krsek M, Bandúrová L, Pecen L, Vladyka V, Liscák R. Is it possible to avoid hypopituitarism after irradiation of pituitary adenomas by the Leksell gamma knife? Eur J Endocrinol. 2011;164:169-78.

37. Sheehan JP, Pouratian N, Steiner L, Laws ER, Vance ML. Gamma Knife surgery for pituitary adenomas: factors related to radiological and endocrine outcomes. J Neurosurg. 2011;114:303-9.

38. Sicignano G, Losa M, del Vecchio A, Cattaneo GM, Picozzi P, Bolognesi A, et al. Dosimetric factors associated with pituitary function after Gamma Knife Surgery (GKS) of pituitary adenomas. Radiother Oncol. 2012;104:119-24.

39. Meeks SL, Buatti JM, Foote KD, Friedman WA, Bova FJ. Calculation of cranial nerve complication probability for acoustic neuroma radiosurgery. Int J Radiat Oncol Biol Phys. 2000;47:597-602.

40. Gondi V, Tomé WA, Mehta MP. Why avoid the hippocampus? A comprehensive review. Radiother Oncol. 2010;97:370-6.
41. Pham CJ, Chang SD, Gibbs IC, Jones P, Heilbrun MP, Adler Jr JR. Preliminary visual field preservation after staged CyberKnife radiosurgery for perioptic lesions. Neurosurgery. 2004;54:799-810.

42. Adler Jr JR, Gibbs IC, Puataweepong P, Chang SD. Visual field preservation after multisession cyberknife radiosurgery for perioptic lesions. Neurosurgery. 2006;59:2442-54.

43. Killory BD, Kresl JJ, Wait SD, Ponce FA, Porter R, White WL. Hypofractionated CyberKnife radiosurgery for perichiasmatic pituitary adenomas: early results. Neurosurgery. 2009;64:A19-25.

44. Iwata H, Sato K, Tatewaki K, Yokota N, Inoue M, Baba Y, et al. Hypofractionated stereotactic radiotherapy with CyberKnife for nonfunctioning pituitary adenoma: high local control with low toxicity. Neuro Oncol. 2011:13:916-22.

45. Liao HI, Wang CC, Wei KC, Chang CN, Hsu YH, Lee ST, et al. Fractionated stereotactic radiosurgery using the Novalis system for the management of pituitary adenomas close to the optic apparatus. J Clin Neurosci. 2014;21:111-5.

46. Minniti G, Esposito V, Clarke E, Scaringi C, Bozzao A, Falco T, De Sanctis V, Enrici MM, Valeriani M, Osti MF, Enrici RM. Fractionated stereotactic radiosurgery for patients with skull base metastases from systemic cancer involving the anterior visual pathway. Radiat Oncol. 2014;9:110.

47. Calcerrada Díaz-Santos N, Blasco Amaro JA, Cardiel GA, Andradas AE. The safety and efficacy of robotic image-guided radiosurgery system treatment for intra- and extracranial lesions: a systematic review of the literature. Radiother Oncol. 2008;89:245-53.

48. Minniti G, Scaringi C, Clarke E, Valeriani M, Osti M, Enrici RM. Frameless linacbased stereotactic radiosurgery (SRS) for brain metastases: analysis of patient repositioning using a mask fixation system and clinical outcomes. Radiat Oncol. 2011;6:158.

49. Rahimian J, Chen JC, Rao AA, Girvigian MR, Miller MJ, Greathouse HE. Geometrical accuracy of the Novalis stereotactic radiosurgery system for trigeminal neuralgia. J Neurosurg. 2004;101 Suppl 3:351-5.

50. Mancosu P, Fogliata A, Stravato A, Tomatis S, Cozzi L, Scorsetti M. Accuracy evaluation of the optical surface monitoring system on EDGE linear accelerator in a phantom study. Med Dosim. 2016:41:173-9.

51. Wurm RE, Erbel S, Schwenkert I, Gum F, Agaoglu D, Schild R, Schlenger L, Scheffler D, Brock M, Budach V. Novalis frameless image-guided noninvasive radiosurgery: initial experience. Neurosurgery. 2008;62(Suppl):A11-7.

52. Solberg TD, Balter JM, Benedict SH, Fraass BA, Kavanagh B, Miyamoto C, et al. Quality and safety considerations in stereotactic radiosurgery and stereotactic body radiation therapy: Executive summary. Pract Radiat Oncol. 2012;2:2-9.

53. World Health Organization (WHO). Radiotherapy Risk Profile, Technical Manual. WHO Press, Geneva, Switzerland; 2008. Available at: http://www. who.int/patientsafety/activities/technical/radiotherapy_risk_profile.pdf. Accessed 18 Aug 2016.

54. Larson DA, Bova FJ, Eisert D. Current radiosurgery practice: results of an ASTRO survey. Task Force on Stereotactic Radiosurgery, American Society for Therapeutic Radiology and Oncology. Int J Radiat Oncol Biol Phys. 1994;28:523-6.

55. Schell MC, Bova FJ, Larson DA. 42 of the American Association of Physicists in Medicine. AAPM Report No. 54: Stereotactic radiosurgery. Report of task group; 1995. Available at: http://www.aapm.org/pubs/reports/RPT_54.pdf. Accessed 18 Aug 2016.

56. ACR Practice Guideline: Practice guideline for the performance of stereotactic of brain stereotactic radiosurgery. American. College or Radiology and American Society for Therapeutic Radiology and Oncology; 2006. Available at: http://www.acr.org/ /media/ f80a2737ffof4753b6ababa73e15d757.pdf. Accessed 18 Aug 2016.

57. Canadian Partnership for Quality Radiotherapy (CPQR). Quality Assurance Guidelines for Canadian Radiation Treatment Programs. A guidance document on behalf of: Canadian Association of Radiation Oncology Canadian Organization of Medical Physicists Canadian Association of Medical Radiation Technologists Canadian Partnership Against Cancer; 2013. Available at : http://www.caro-acro.ca/assets/cpqr.pdf. Accessed 20 Aug 2016

58. Sheehan JP, Kondziolka D, Flickinger J, Lunsford LD. Radiosurgery for residualor recurrent nonfunctioning pituitary adenoma. J Neurosurg. 2002; 97(Suppl):408-14

59. Wowra B, Stummer W. Efficacy of gamma knife radiosurgery for nonfunctioning pituitary adenomas: a quantitative follow-up with magnetic resonance imaging-based volumetric analysis. J Neurosurg. 2002;97:429-32. 
60. Petrovitch Z, Yu C, Giannotta SL, Zee CS, Apuzzo ML. Gamma knife radiosurgery for pituitary adenoma: early results. Neurosurgery. 2003;53:51-9.

61. Losa M, Valle M, Mortini P, Franzin A, da Passano CF, Cenzato M, et al. Gamma knife surgery for treatment of residual nonfunctioning pituitary adenomas after surgical debulking. J Neurosurg. 2004;100:438-44.

62. Muacevic A, Uhl E, Wowra B. Gamma knife radiosurgery for nonfunctioning pituitary adenomas. Acta Neurochir Suppl. 2004;91:51-4.

63. Picozzi $P$, Losa M, Mortini P, Valle MA, Franzin A, Attuati L, Ferrari da Passano C, Giovanelli M. Radiosurgery and the prevention of regrowth of incompletely removed nonfunctioning pituitary adenomas. J Neurosurg. 2005;102(Suppl):71-4.

64. Iwai Y, Yamanaka K, Yoshioka K. Radiosurgery for nonfunctioning pituitary adenomas. Neurosurgery. 2005;56:699-705.

65. Mingione $V$, Yen CP, Vance ML, Steiner M, Sheehan J, Laws ER, et al. Gamma surgery in the treatment of nonsecretory pituitary macroadenoma. J Neurosurg. 2006;104:876-83.

66. Voges J, Kocher M, Runge M, Poggenborg J, Lehrke R, Lenartz D, et al. Linear accelerator radiosurgery for pituitary macroadenomas: a 7-year follow-up study. Cancer. 2006;107:1355-564.

67. Liscák R, Vladyka V, Marek J, Simonová G, Vymazal J. Gamma knife radiosurgery for endocrine-inactive pituitary adenomas. Acta Neurochir (Wien). 2007;149:999-1006.

68. Pollock BE, Cochran J, Natt N, Brown PD, Erickson D, Link MJ, et al. Gamma knife radiosurgery for patients with nonfunctioning pituitary adenomas: results from a 15-year experience. Int J Radiat Oncol Biol Phys. 2008;70:1325-9.

69. Kobayashi T. Long-term results of stereotactic gamma knife radiosurgery for pituitary adenomas. Specific strategies for different types of adenoma. Prog Neurol Surg. 2009;22:77-95

70. Hayashi M, Chernov M, Tamura N, Nagai M, Yomo S, Ochiai T, et al. Gamma Knife robotic microradiosurgery of pituitary adenomas invading the cavernous sinus: treatment concept and results in 89 cases. J Neurooncol. 2010;98:185-94.

71. Gopalan R, Schlesinger D, Vance ML, Laws E, Sheehan J. Long-term outcomes after Gamma Knife radiosurgery for patients with a nonfunctioning pituitary adenoma. Neurosurgery. 2011;69:284-93.

72. Park KJ, Kano H, Parry PV, Niranjan A, Flickinger JC, Lunsford LD, et al. Longterm outcomes after gamma knife stereotactic radiosurgery for nonfunctional pituitary adenomas. Neurosurgery. 2011;69:1188-899.

73. Starke RM, Williams BJ, Jane Jr JA, Sheehan JP. Gamma Knife surgery for patients with nonfunctioning pituitary macroadenomas: predictors of tumor control, neurological deficits, and hypopituitarism. J Neurosurg. 2012;117:129-35.

74. Runge MJ, Maarouf M, Hunsche S, Kocher M, Ruge MI, El Majdoub F, et al. LINAC-radiosurgery for nonsecreting pituitary adenomas. Long-term results. Strahlenther Onkol. 2012;188:319-25.

75. Wilson PJ, De-Loyde KJ, Williams JR, Smee RI. A single centre's experience of stereotactic radiosurgery and radiotherapy for non functioning pituitary adenomas with the Linear Accelerator (Linac). J Clin Neurosci. 2012;19:1370-4.

76. Sheehan JP, Starke RM, Mathieu D, Young B, Sneed PK, Chiang VL, et al. Gamma Knife radiosurgery for the management of nonfunctioning pituitary adenomas: a multicenter study. J Neurosurg. 2013;119:446-56.

77. Lee CC, Kano H, Yang HC, Xu Z, Yen CP, Chung WY, et al. Initial Gamma Knife radiosurgery for nonfunctioning pituitary adenomas. J Neurosurg. 2014;120:647-54.

78. Bir SC, Murray RD, Ambekar S, Bollam P, Nanda A. Clinical and Radiologic Outcome of Gamma Knife Radiosurgery on Nonfunctioning Pituitary Adenomas. J Neurol Surg B Skull Base. 2015;76:351-7.

79. Pomeraniec IJ, Dallapiazza RF, Xu Z, Jane Jr JA, Sheehan JP. Early versus late Gamma Knife radiosurgery following transsphenoidal resection for nonfunctioning pituitary macroadenomas: a matched cohort study. J Neurosurg. 2016;125:202-12.

80. Minniti G, Esposito V, Piccirilli M, Fratticci A, Santoro A, Jaffrain-Rea ML. Diagnosis and management of pituitary tumours in the elderly: a review based on personal experience and evidence of literature. Eur J Endocrinol. 2005; 153:723-35.

81. Adler Jr JR, Gibbs IC, Puataweepong P, Chang SD. Visual field preservation after multisession cyberknife radiosurgery for perioptic lesions. Neurosurgery. 2006;59:244-54.

82. Roberts BK, Ouyang DL, Lad SP, Chang SD, Harsh 4th GR, Adler Jr JR, et al. Efficacy and safety of CyberKnife radiosurgery for acromegaly. Pituitary. 2007;10:19-25.
83. Haghighi N, Seely A, Paul E, Dally M. Hypofractionated stereotactic radiotherapy for benign intracranial tumours of the cavernous sinus. J Clin Neurosci. 2015;22:1450-5.

84. Zhang N, Pan L, Wang EM, Dai JZ, Wang BJ, Cai PW. Radiosurgery for growth hormone-producing pituitary adenomas. J Neurosurg. 2000; 93(Suppl):6-9.

85. Izawa M, Hayashi M, Nakaya K, Satoh H, Ochiai T, Hori T, Takakura K. Gamma knife radiosurgery for pituitary adenomas. J Neurosurg. 2000; 93(Suppl):19-22.

86. Attanasio R, Epaminonda P, Motti E, Giugni E, Ventrella L, Cozzi R, et al. Gamma-knife radiosurgery in acromegaly: a 4-year follow-up study. J Clin Endocrinol Metab. 2003:88:3105-12.

87. Jane J, Vance ML, Woodburn CJ, Laws Jr ER. Stereotactic radiosurgery for hypersecreting pituitary tumors: part of a multimodality approach. Neurosurg Focus. 2003;14:e12.

88. Castinetti F, Taieb D, Kuhn JM, Chanson P, Tamura M, Jaquet $P$, et al. Outcome of gamma knife radiosurgery in 82 patients with acromegaly: correlation with initial hypersecretion. J Clin Endocrinol Metab. 2005;90:4483-8.

89. Gutt B, Wowra B, Alexandrov R, Uhl E, Schaaf L, Stalla GK, et al. Gamma-knife surgery is effective in normalising plasma insulin-like growth factor I in patients with acromegaly. Exp Clin Endocrinol Diabetes. 2005;113:219-24.

90. Kobayashi T, Mori Y, Uchiyama Y, Kida Y, Fujitani S. Long-term results of gamma knife surgery for growth hormone-producing pituitary adenoma: is the disease difficult to cure? J Neurosurg. 2005;102:119-23.

91. Jezková J, Marek J, Hána V, Krsek M, Weiss V, Vladyka V, et al. Gamma knife radiosurgery for acromegaly-long-term experience. Clin Endocrinol (Oxf). 2006;64:588-95.

92. Petit JH, Biller BM, Coen JJ, Swearingen B, Ancukiewicz M, Bussiere M, Chapman P, Klibanski A, Loeffler JS. Proton stereotactic radiosurgery in management of persistent acromegaly. Endocr Pract. 2007;13:726-34.

93. Pollock BE, Jacob JT, Brown PD, Nippoldt TB. Radiosurgery of growth hormone-producing pituitary adenomas: factors associated with biochemical remission. J Neurosurg. 2007;106:833-8.

94. Vik-Mo EO, Oksnes M, Pedersen PH, Wentzel-Larsen T, Rødahl E, Thorsen F, et al. Gamma knife stereotactic radiosurgery for acromegaly. Eur J Endocrinol. 2007;157:255-63.

95. Jagannathan J, Sheehan JP, Pouratian N, Laws Jr ER, Steiner L, Vance ML. Gamma knife radiosurgery for acromegaly: outcomes after failed transsphenoidal surgery. Neurosurgery. 2008;62:1262-9.

96. Losa M, Gioia L, Picozzi P, Franzin A, Valle M, Giovanelli $M$, et al. The role of stereotactic radiotherapy in patients with growth hormone-secreting pituitary adenoma. J Clin Endocrinol Metab. 2008;93:2546-52.

97. Ronchi CL, Attanasio R, Verrua E, Cozzi R, Ferrante E, Loli P, et al. Efficacy and tolerability of gamma knife radiosurgery in acromegaly: a 10-year follow-up study. Clin Endocrinol (Oxf). 2009;71:846-52.

98. Wan H, Chihiro O, Yuan S. MASEP gamma knife radiosurgery for secretory pituitary adenomas: experience in 347 consecutive cases. J Exp Clin Cancer Res. 2009;11:28-36.

99. Iwai Y, Yamanaka K, Yoshimura M, Kawasaki I, Yamagami K, Yoshioka K. Gamma knife radiosurgery for growth hormone-producing adenomas. J Clin Neurosci. 2010;17:299-304.

100. Castinetti F, Nagai M, Morange I, Dufour H, Caron P, Chanson P, et al. Longterm results of stereotactic radiosurgery in secretory pituitary adenomas. J Clin Endocrinol Metab. 2009:94:3400-7.

101. Poon TL, Leung SC, Poon CY, Yu CP. Predictors of outcome following Gamma Knife surgery for acromegaly. J Neurosurg. 2010;113(Suppl):149-52.

102. Erdur FM, Kilic T, Peker S, Celik O, Kadioglu P. Gammaknife radiosurgery in patients with acromegaly. J Clin Neurosci. 2011;18:1616-20.

103. Franzin A, Spatola G, Losa M, Picozzi P, Mortini P. Results of gamma knife radiosurgery in acromegaly. Int J Endocrinol. 2012;2012:342034.

104. Liu X, Kano H, Kondziolka D, Park KJ, Iyer A, Niranjan A, et al. Gamma knife radiosurgery for clinically persistent acromegaly. J Neurooncol. 2012;109:71-9.

105. Zeiler FA, Bigder M, Kaufmann A, McDonald PJ, Fewer D, Butler J, et al. Gamma knife in the treatment of pituitary adenomas: results of a single center. Can J Neurol Sci. 2013;40:546-52.

106. Yan JL, Chang CN, Chuang CC, Hsu PW, Lin JD, Wei KC, et al. Long-term follow-up of patients with surgical intractable acromegaly after linear accelerator radiosurgery. J Formos Med Assoc. 2013:112:416-20. 
107. Wilson PJ, De-Loyde KJ, Williams JR, Smee RI. Acromegaly: a single centre's experience of stereotactic radiosurgery and radiotherapy for growth hormone secreting pituitary tumours with the linear accelerator. J Clin Neurosci. 2013;20:1506-13.

108. Lee CC, Vance ML, Xu Z, Yen CP, Schlesinger D, Dodson B, Sheehan J. Stereotactic radiosurgery for acromegaly. J Clin Endocrinol Metab. 2014; 99:1273-81.

109. Wattson DA, Tanguturi SK, Spiegel DY, Niemierko A, Biller BM, et al. Outcomes of proton therapy for patients with functional pituitary adenomas. Int J Radiat Oncol Biol Phys. 2014;90:532-9.

110. Boström JP, Kinfe T, Meyer A, Pintea B, Gerlach R, et al. Treatment of acromegaly patients with risk-adapted single or fractionated stereotactic high-precision radiotherapy: High local control and low toxicity in a pooled series. Strahlenther Onkol. 2015;191:477-85.

111. Landolt AM, Haller D, Lomax N, Scheib S, Schubiger O, Siegfried J, et al. Stereotactic radiosurgery for recurrent surgically treated acromegaly: comparison with fractionated radiotherapy. J Neurosurg. 1998;88:1002-8.

112. Morange-Ramos I, Regis J, Dufour H, Andrieu JM, Grisoli F, Jaquet $P$, et al. Short term endocrinological results after gamma knife surgery of pituitary adenomas. Stereotact Funct Neurosurg. 1998;70:127-38.

113. Sheehan JM, Vance ML, Sheehan JP, Ellegala DB, Laws Jr ER. Radiosurgery for Cushing's disease after failed transsphenoidal surgery. J Neurosurg. 2000;93:738-42.

114. Höybye C, Grenbäck E, Rähn T, Degerblad M, Thorén M, Hulting AL. Adrenocorticotropic hormone-producing pituitary tumors: 12- to 22-year follow-up after treatment with stereotactic radiosurgery. Neurosurgery. 2001;49:284-91.

115. Devin JK, Allen GS, Cmelak AJ, Duggan DM, Blevins LS. The efficacy of linear accelerator radiosurgery in the management of patients with Cushing's disease. Stereotact Funct Neurosurg. 2004;82:254-62.

116. Castinetti F, Nagai M, Dufour H, Kuhn JM, Morange I, Jaquet P, et al. Gamma knife radiosurgery is a successful adjunctive treatment in Cushing's disease. Eur J Endocrinol. 2007;156:91-8.

117. Jagannathan J, Sheehan JP, Pouratian N, Laws ER, Steiner L, Vance ML. Gamma Knife surgery for Cushing's disease. J Neurosurg. 2007;106:980-7.

118. Pollock BE, Brown PD, Nippoldt TB, Young Jr WF. Pituitary tumor type affects the chance of biochemical remission after radiosurgery of hormonesecreting pituitary adenomas. Neurosurgery. 2008:62:1271-6.

119. Tinnel BA, Henderson MA, Witt TC, Fakiris AJ, Worth RM, Des Rosiers PM, et al. Endocrine response after gamma knife-based stereotactic radiosurgery for secretory pituitary adenoma. Stereotact Funct Neurosurg. 2008;86:292-6.

120. Wein L, Dally M, Bach LA. Stereotactic radiosurgery for treatment of Cushing disease: an Australian experience. Intern Med J. 2012;42:1153-6.

121 Grant RA, Whicker M, Lleva R, Knisely JP, Inzucchi SE, Chiang VL. Efficacy and Safety of Higher Dose Stereotactic Radiosurgery for Functional Pituitary Adenomas: A Preliminary Report. World Neurosurg. 2013;195:201.

122 Sheehan JP, Xu Z, Salvetti DJ, Schmitt PJ, Vance ML. Results of gamma knife surgery for Cushing's disease. J Neurosurg. 2013;119:1486-92.

123 Wilson PJ, Williams JR, Smee RI. Cushing's disease: a single centre's experience using the linear accelerator (LINAC) for stereotactic radiosurgery and fractionated stereotactic radiotherapy. J Clin Neurosci. 2014;21:100-6.

124 Landolt AM, Lomax N. Gamma knife radiosurgery for prolactinomas. J Neurosurg. 2000;93:14-8.

125 Pan L, Zhang N, Wang EM, Wang BJ, Dai JZ, Cai PW. Gamma knife radiosurgery as a primary treatment for prolactinomas. J Neurosurg. 2000;93:10-3.

126 Choi JY, Chang JH, Chang JW, Ha Y, Park YG, Chung SS. Radiological and hormonal responses of functioning pituitary adenomas after gamma knife radiosurgery. Yonsei Med J. 2003;44:602-7.

127 Pouratian N, Sheehan J, Jagannathan J, Laws Jr ER, Steiner L, Vance ML. Gamma knife radiosurgery for medically and surgically refractory prolactinomas. Neurosurgery. 2006:59:255-66.

128 Jezková J, Hána V, Krsek M, Weiss V, Vladyka V, Liscák R, et al. Use of the Leksell gamma knife in the treatment of prolactinoma patients. Clin Endocrinol (Oxf). 2009;70:732-41.

129 Tanaka S, Link MJ, Brown PD, Stafford SL, Young Jr WF, Pollock BE. Gamma knife radiosurgery for patients with prolactin-secreting pituitary adenomas. World Neurosurg. 2010;74:147-52.

130 Liu X, Kano H, Kondziolka D, Park KJ, Iyer A, Shin S, et al. Gamma knife stereotactic radiosurgery for drug resistant or intolerant invasive prolactinomas. Pituitary. 2013;16:68-75.
131 Cohen-Inbar O, Xu Z, Schlesinger D, Vance ML, Sheehan JP. Gamma Knife radiosurgery for medically and surgically refractory prolactinomas: long-term results. Pituitary. 2015;18:820-30.

132 Milker-Zabel S, Debus J, Thilmann C, Schegel W, Wannenmacher M. Fractionated stereotactically guided radiotherapy and radiosurgery in the treatment of functional and non-functional adenomas of the pituitary gland. Int J Radiat Oncol Biol Phys. 2001;50:1279-88.

133 Milker-Zabel S, Zabel A, Huber P, Schlegel W, Wannenmacher M, Debus J. Stereotactic conformal radiotherapy in patients with growth hormonesecreting pituitary adenoma. Int J Radiat Oncol Biol Phys. 2004;59:1088-96.

134 Paek SH, Downes MB, Bednarz G, Keane WM, Werner-Wasik M, Curran Jr WJ, et al. Integration of surgery with fractionated stereotactic radiotherapy for treatment of nonfunctioning pituitary macroadenomas. Int J Radiat Oncol Biol Phys. 2005;61:795-808.

135 Colin P, Jovenin N, Delemer B, Caron J, Grulet H, Hecart AC, et al. Treatment of pituitary adenomas by fractionated stereotactic radiotherapy: a prospective study of 110 patients. Int J Radiat Oncol Biol Phys. 2005;62:333-41.

136 Minniti G, Traish D, Ashley S, Gonsalves A, Brada M. Fractionated stereotactic conformal radiotherapy for secreting and nonsecreting pituitary adenomas. Clin Endocrinol (Oxf). 2006;64:542-8.

137 Kong DS, Lee Jl, Lim do H, Kim KW, Shin HJ, Nam DH, et al. The efficacy of fractionated radiotherapy and stereotactic radiosurgery for pituitary adenomas: long-term results of 125 consecutive patients treated in a single institution. Cancer. 2007;110:854-60.

138 Roug S, Rasmussen AK, Juhler M, Kosteljanetz M, Poulsgaard L, Heebøll H, et al. Fractionated stereotactic radiotherapy in patients with acromegaly: an interim single-centre audit. Eur J Endocrinol. 2010;162:685-894.

139 Schalin-Jäntti C, Valanne L, Tenhunen M, Setälä K, Paetau A, Sane T, et al. Outcome of fractionated stereotactic radiotherapy in patients with pituitary adenomas resistant to conventional treatments: a 5.25-year follow-up study. Clin Endocrinol (Oxf). 2010;73:72-7.

140 Kopp C, Theodorou M, Poullos N, Astner ST, Geinitz H, Stalla GK, et al. Fractionated stereotactic radiotherapy in the treatment of pituitary adenomas. Strahlenther Onkol. 2013;189:932-7.

141 Kim JO, Ma R, Akagami R, McKenzie M, Johnson M, Gete E, Nichol A. Long-term outcomes of fractionated stereotactic radiation therapy for pituitary adenomas at the BC Cancer Agency. Int J Radiat Oncol Biol Phys. 2013;87:528-33

142 Minniti G, Scaringi C, Poggi M, Jaffrain Rea ML, Trillò G, Esposito V, et al. Fractionated stereotactic radiotherapy for large and invasive nonfunctioning pituitary adenomas: long-term clinical outcomes and volumetric MRI assessment of tumor response. Eur J Endocrinol. 2015;172:433-41.

\section{Submit your next manuscript to BioMed Central and we will help you at every step:}

- We accept pre-submission inquiries

- Our selector tool helps you to find the most relevant journal

- We provide round the clock customer support

- Convenient online submission

- Thorough peer review

- Inclusion in PubMed and all major indexing services

- Maximum visibility for your research

Submit your manuscript at www.biomedcentral.com/submit 